\title{
Implementasi Nilai-Nilai Pendidikan Multikultural di Perguruan Tinggi (Studi Kasus di Prodi PGSD Universitas PGRI Palembang Sumatera Selatan)
}

\author{
Miftahul Husni \\ Universitas Negeri Islam Negeri Raden Fatah Palembang \\ miftahulhusni_uin@radenfatah.ac.id
}

\begin{abstract}
The Republic of Indonesia is a country that has a very heterogeneous and pluralistic population, starting from religion, ethnicity, culture and also language. So the motto of this country is "Binneka Tunggal Ika" which means different but still one. So of course to be a safe and peaceful country must respect and respect differences. But a few years ago, togetherness and mutual respect for differences began to be shaken by the emergence of identity politics, with the emergence of identity politics resulting in the formation of two major groups, namely the moslem group which became the largest population and also non-Islamic groups, between the two groups occurring extraordinary friction, plus irresponsible elements of the two groups become scissors that always damage and disintegrate the community through posting on their respective social media, in addition to that hoaks information also has a negative impact on the poor attitude of the Indonesian people's tolerance . then with these welds researchers want to see how the values of multicultural education are implemented in the university area. The focus of the problem in this research are, 1 . How are the principles of planting multicultural education values at PGRI University in Palembang ?, 2. How about planting multicultural education values at PGRI Palembang University?, 3. What are the implications of planting educational values multicultural toward the tolerance attitude of Palembang PGRI University students?. This type of research is a qualitative descriptive research, using observational data collection, interviews and documentation. The data analysis technique is triangulation (data reduction, data display, and drawing conclusions). The results of the study explained that there are three principles of multicultural education values at PGRI university, including the principles of democracy, equality and justice, these three principles are the foundation for the application of multicultural education values at PGRI University, then the implementation of educational values multiculturalism is carried out through formal and non-formal education, in addition to that campus services also highly uphold multicultural values.
\end{abstract}

Keywords: Implementation, Multicultural Education V alues, PGRI University

AR-RIAYAH : Jurnal Pendidikan Dasar vol. 3, no. 2, 2019

IAIN Curup - Bengkulu| pISSN2580-362X; eISSN2580-3611

http://journal.iaincurup.ac.id/index.php/JPD 


\begin{abstract}
Abstrak: Negara republik Indonesia merupakan negara yang hetrogen dan pluralis, mulai dari agama, suku, budaya dan juga bahasa. Hal tersebut sesuai dengan semboyan dari negara ini adalah "Binneka Tunggal Ika” yang artinya berbeda-beda namun tetap satu. Maka untuk menjadi negara yang aman damai dan sejahtera harus menghargai dan menghormati perbedaan. Namun beberapa tahun yang silam, kebersamaan dan sikap saling menghargai perbedaan mulai digoncang dengan munculnya poliitik identitas, dengan munculnya politik identitas mengakibatkan terbentuknya dua golongan besar, yakni golongan ummat Islam yang menjadi populasi paling besar dan juga golongan non Islam, antara dua golongan tersebut terjadi gesekan yang luar biasa, ditambah lagi oknum yang tidak bertanggung jawab dari dua golongan tersebut menjadi gunting yang selalu merusak dan mencerai beraikan masyarakat lewat postingan dimedia sosialnya masing-masing, selain itu juga informasi hoaks juga memberikn dampak negatif terhadap buruknya sikap toleransi masyarakat Indonesia. Hasil penelitan menjelaskan bahwa prinsip nilai-nilai pendidikan multikultural di universitas PGRI ada tiga, antara lain adalah prinsip demokrasi, kesetaraan dan keadilan, tiga prinsip ini yang menjadi pondasi penerapan nilai-nilai pendidikan multikultural di Univesitas PGRI, selanjutnya Implementasi nilai-nilai pendidikan multikultural dilaksanakan melalui pendidikan formal dan non formal, selain itu pelayanan kampus juga sangat menjungjung tinggi nilai-nilai multikultural.
\end{abstract}

Kata Kunci: Implementasi, Nilai, Pendidikan Multikultural, Universitas PGRI

\title{
PENDAHULUAN
}

Negara Republik Indonesia adalah negara yang mempunyai penduduk yang sangat hetrogen dan pluralis, mulai dari agama, suku, budaya dan juga bahasa. Maka yang menjadi semboyan dari negara ini adalah "Binneka Tunggal Ika" yang artinya berbeda-beda namun tetap satu. Maka tentunya untuk menjadi negara yang aman damai dan sejahtera harus menghargai dan menghormati perbedaan. Namun kebersamaan dan dan saling menghargai perbedaan mulai digoncang dengan munculnya politik identitas. Politik identitas tersebut mengakibatkan terbentuknya dua golongan besar, yakni golongan ummat Islam yang menjadi populasi paling besar dan juga golongan non Islam sebagai populasi kedua, antara dua golongan tersebut terjadi gesekan yang luar biasa disebabkan politik yang mengatasnamakan keagamaan dan ini menjadi faktor paling kuat terjadinya gesekan antar ummat beragama di Indonesia.

Kemudian ditambah lagi oknum-oknum yang tidak bertanggung jawab dari dua golongan tersebut yang mempunyai peran penting dalam merusak dan mencerai beraikan masyarakat lewat postingan di media sosial. Konten postingan tersebut banyak mengaitkan politik dengan agama, bahkan 
mendeskriditkan agama tertentu untuk memuluskan pasangan calon tertentu yang didukungnya, selain itu juga informasi-informasi hoaks yang belakangan ini banyak beredar juga mempunyai peran penting merusak tatanan toleransi di Indonesia yang sudah lama terbagun., maka dengan itu universitas menjadi salah satu wadah untuk meminimalisir sikap-sikap intoleransi yang sudah berkembang dimasyarakat, penanaman sikap toleransi melalui implementasi nilai-nilai pendidikan multikultural dianggap menjadi peredam gasekan antar umat beragama.

Tentunya, dengan alasan tersebut peneliti ingin menganalisis peran universitas dalam mengimplementasikan nilai-nilai pendidikan multikultural. Universitas PGRI dipilih sebagai tempat penelitian karena kampus tersebut memiliki mahasiswa yang hetrogen dan multikultural.

\section{METODOLOGI}

Penelitian dilakukan dengan pendekatan kualitatif. Pendekatan kualitatif yaitu strategi dan teknik penelitian yang digunakan untuk memahami masyarakat, masalah atau gejala dalam masyarakat dengan mengumpulkan sebanyak mungkin fakta mendalam, data disajikan dalam bentuk verbal bukan bentuk angka. ${ }^{1}$ Sedangkan alat pengumpulan data dengan menggunakan observasi, wawancara dan dokumentasi.

Observasi dilakukan selama lebih kurang dua bulan, dengan rangkaian kegiatan yang meliputi observasi umum terhadap kegiatan yang dilaksanakan di Universitas PGRI Palembang dan observasi khusus terhadap implementasi pendidikan multikultural. Kondisi secara umum di universitas tersebut juga akan menjadi obyek pengamatan penulis. Hasil observasi tersebut akan dituangkan pada lembar lampiran dalam penelitian ini sebagai bukti penelitian.

Peneliti juga menggunakan wawancara bebas terpimpin, yaitu peneliti membawa pedoman yang merupakan garis besar tentang hal-hal yang ditanyakan. Adapun data-data yang diperoleh dari wawancara ini adalah mengenai prinsip pendidikan di Universitas PGRI Palembang, penanaman nilai multikultural dan implikasi pendidikan mulitkultural di Universitas PGRI. Hasil wawancara tersebut akan dituangkan pada lembar lampiran dalam penelitian ini sebagai bukti penelitian. Tehnik wawancara dipergunakan karena merupakan salah satu teknik pengumpulan data yang relevan dengan tujuan penelitian kualitatif.

Kemudian tahap dokumentasi yang merupakan catatan peristiwa yang sudah berlalu dan dapat berupa tulisan, gambar, atau karya-karya monumental dari seseorang. Jadi, metode dokumentasi adalah suatu metode yang digunakan

1 Arikunto, Suharsimi, Prosedur Penelitian Suatu Pendekatan Praktek, Jakarta: Rineka Cipta, 1996), hlm. 20 
dalam melakukan penelitian dengan jalan mencatat data-data, catatan resmi dari berbagai sumber yang terkait dengan penelitian. Adapun data-data yang diperoleh dalam metode ini adalah data-data atau catatan yang terkait dengan, sejarah pendirian, profil perguruan tinggi, dokumen tentang dosen dan mahasiswa, dokumen peraturan universitas, atau foto-foto kegiatan implimentasi pendidikan multikultural di Universitas PGRI. Kelebihan dari studi dokumentasi adalah data yang diperoleh stabil dan tidak cepat berubahubah dan apabila terjadi kekeliruan atau kekurangan data dalam pembahasan maka dapat ditelusuri kembali dari sumber data yang sama dan kondisinya tidak banyak berubah.

Teknis analisis data dalam penelitian ini menggunakan model analisis interaktif. Dimana ada 3 (tiga) tahapan yakni : (1) Reduksi data, (2) Display data, (3) Mengambil kesimpulan dan verifikasi. ${ }^{2}$

1. Reduksi data

Reduksi data merupakan langkah awal dalam menganalisis data. Reduksi data dilakukan untuk memudahkan pemahaman terhadap data yang telah dikumpulkan. Pada tahapan reduksi data peneliti membuat rangkuman terhadap aspek-aspek permasalahan yang diteliti sehingga memudahkan dalam melakukan langkah-langkah analisis selanjutnya.

2. Display Data

Display data merupakan upaya menyajikan data untuk melihat gambaran keseluruhan data atau bagian-bagian tertentu dari penelitian. Keseluruhan dirancang untuk menggabungkan informasi yang disusun dalam suatu bentuk paduan dan mudah dilihat, sehingga peneliti dapat memahami data dan tidak larut dalam lautan data. Sehingga peneliti melakukan pengelompokan data dan memilih data yang menjadi pendukung penelitian. Setelah dilakukan reduksi data, langkah selanjutnya menyajikan data secara jelas dan singkat. Selanjutnya dilakukan penafsiran data sampai dengan pengambilan keputusan melalui penyajian data.

3. Kesimpulan dan Verifikasi

Pengambilan kesimpulan pada tahap ini dilakukan secara bertahap, pertama menyusun kesimpulan sementara setelah data bertambah dilakukan verifikasi. Kegiatan verifikasi dilakukan dengan cara mempelajari data yang telah direduksi maupun data yang telah disajikan. Selain itu, kegiatan ini dilakukan dengan cara meminta pertimbangan kepada orang yang berkompeten misalnya pengelola yayasan dan atau kepala sekolah. Dalam penelitian ini, verifikasi dilakukan secara berkesinambungan atau terus menerus selama penelitian berlangsung sehingga diperoleh kesimpulan akhir yang kokoh.

\footnotetext{
2 Sugiyono, Metode Penelitian Kuantitatif, Kualitatif dan R\&D, (Bandung: Alfabeta, 2009),
} 


\section{KAJIAN TEORI}

\section{Pengertian Pendidikan Multikultural}

Secara etimologis, istilah pendidikan multikultural terdiri dari dua kata, yaitu pendidikan dan multikultural. Kata "pendidikan" dalam beberapa referensi diartikan sebagai proses pengembangan sikap dan tata laku seseorang atau sekelompok orang dalam usaha mendewasakan manusia melalui upaya pengajaran, pelatihan, proses, pembuatan, dan cara-cara yang mendidik. Sementara itu, kata "multikultural" berasal dari kata "multi" yang berarti banyak, ragam, dan aneka. Sedangkan kata "culture" memiliki makna yaitu kebudayaan, kesopanan, dan pemeliharaan. Atas dasar ini, multikultural diartikan bahwa keragaman budaya sebagai bentuk dari keragaman latar belakang seseorang. Dengan kata lain, multikultural adalah keberagaman budaya. Sementara secara etimologi, istilah multikulturalisme dibentuk dari kata multi (banyak), kultur (budaya), dan isme (aliran/paham). Adapun secara hakiki, dalam kata multikulturalisme itu terkandung pengakuan akan martabat manusia yang hidup dalam komunitasnya dengan kebudayaannya masing-masing yang unik. Sedangkan, kultur (budaya) itu sendiri tidak bisa dilepaskan dari empat tema penting yaitu: agama (aliran), ras (etnis), suku, dan budaya. Hal ini mengandung arti bahwa pembahasan multikultur mencakup tidak hanya perbedaan budaya saja, melainkan masuk pula di dalamnya kemajemukan agama, ras maupun etnik. ${ }^{3}$

Multikulturalisme ini pun suatu konsep di mana sebuah komunitas dalam konteks kebangsaan dapat mengakui keberagamaan, perbedaan dan kemajemukan budaya, baik ras, suku, etnis, dan agama. Sebuah konsep yang memberikan pemahaman kita bahwa sebuah bangsa yang plural atau majemuk adalah bangsa yang dipenuhi dengan budaya-budaya yang beragam atau multikultur. Bangsa yang multikultur adalah bangsa yang terdiri dari kelompok-kelompok etnik atau budaya yang ada dapat hidup berdampingan secara damai dalam prinsip co-existence yang ditandai oleh kesediaan untuk menghormati budaya lain. ${ }^{4}$

James Banks memaknai pendidikan multikultural sebagai sebuah gagasan yang menjelaskan bahwa semua peserta didik tanpa memandang dari kelompok mana mereka masuk, seperti yang terkait dengan gender, suku bangsa, ras, budaya, kelas sosial, agama tanpa pengecualian, seharusnyaa mengalami kesetaraan pendidikan di sekolah. ${ }^{5}$ Berbeda dengan Kamanto Sunarto yang menyoroti pendidikan multikultural sebagai pendidikan keragaman budaya dalam masyarakat, bisa juga diartikan sebagai

3 Choirul Mahfud, Pendidikan Multikultural, (Yogyakarta: Pustaka Pelajar, 2010), hlm. 75

4 Salmiwati, Urgensi Pendidikan Agama Islam dalam Pengembangan Nilai-NilaiMultikultural, Jurnal Al-Ta lim (Vol. 20, No. 1, 2013), hlm. 337

5 Ali Maksum, Pluralisme dan Multikulturalisme; Paradigma Baru Pendidikan Agama Islam diIndonesia (Malang: Aditya Media Publishing, 2011), 203. 
pendidikan yang menawarkan ragam model untuk keragaman budaya dalam masyarkat, dan terkadang juga dimaknai sebagai pendidikan untuk membina sikap peserta didik agar menghargai keragaman budaya masyarakat. $^{6}$

Sedangkan Ainur Rofiq Dawam memaknai pendidikan multikultural sebagai proses pengembangan seluruh potensi manusia yang menghargai pluralitas dan heterogenitasnya sebagai konsekuensi keragaman budaya, etnis, suku, dan aliran (agama). Melalui pendidikan multikultural ini diharapkan adanya penghormatan dan penghargaan setinggi-tingginya terhadap harkat dan martabat manusia darimanapun dia berasal dan apapun budayanya. Sehingga tercipta kedamaian yang sejati, keamanan tanpa adanya kecemasan dan ketakutan, kesejahteraan tanpa manipulasi, dan kebahagiaan tanpa rekayasa sosial. ${ }^{7}$

Hal ini senada dengan apa yang dinyatakan oleh Prudence Crandall, dalam Dardi Hasyim yang mengemukakan bahwa pendidikan multikultural adalah pendidikan yang memperhatikan secara sungguh-sungguh terhadap latar belakang peserta didik baik dari aspek keragaman suku (etnis), ras, agama (aliran kepercayaan) dan budaya (kultur). ${ }^{8}$

Sementara itu, James A. Banks menyatakan bahwa pendidikan multikultular memiliki lima dimensi yang saling berkaitan, yaitu:

a. Content integration, yaitu mengintegrasikan berbagai budaya dan kelompok untuk mengilustrasikan konsep mendasar, generalisasi dan teori dalam mata pelajaran atau disiplin ilmu.

b. The Knowledge Construction Process, yaitu membawa siswa untuk memahami, menyelidiki, menentukan bagaimana melibatkan penerimaan budaya, dari berbagai bingkai perspektif yang dengannya dibangun sebuah konstruksi pengetahun yang baru.

c. An Equity Pedagogy, yaitu menyesuaikan metode pengajaran dengan cara belajar siswa dalam rangka memfasilitasi prestasi akademik siswa yang beragam baik dari segi ras, budaya ataupun strata sosial.

d. Prejudice Reduction, yaitu fokus pada karakter-karakter dan nilai-nilai kebudayaan peserta didik yang dengannya pendidik dapat memodifikasi pembelajarannya.

e. An empowering school culture, yang bisa dilakukan dengan melatih kelompok untuk berpartisipasi dalam olahraga, berinteraksi dengan seluruh staff dan siswa yang berbeda etnis dan ras dalam upaya

6 Robert E. Slavin, Psikologi Pendidikan; Teori dan Praktik, terj. Marianto Samosir (Jakarta: Indeks, 2011), 152.

7 Ngainun Naim dan Achmad Sauqi, Pendidikan Multikultural: Konsep dan Aplikasi, (Jogjakarta: Ar-Ruzz Media, 2012), Hlm 50

8 H.A. Dardi Hasyim dan Yudi Hartono, Pendidikan Multikultural di Sekolah, (Surakarta: UPT penerbitan dan percetakan UNS, 2009), hlm. 28 
menciptakan budaya akademik. ${ }^{9}$

Sedangkan Gay memandang pendidikan multikultural dari sisi berbeda yakni pendidikan multikultural dipandang sebagai politik pendidikan yang mencantumkan dalam kehidupan dan undang-undang terhadap perbedaan budaya yang berlandaskan kepada filsafat pendidikan dengan tujuan murid mencapai akademik yang persamaan, isi program pendidikan, materi ajar dan structur organisasi yang menjadi aturan seluruh unsur-unsur pendidikan, serta berprinsip pada kemajemukan, peraturan dan nilai. ${ }^{10}$

Memperhatikan definisi pendidikan multikultural yang telah dibahas, dapat diperoleh 3 (tiga) karakteristik pendidikan multikultural sebagai berikut: (1) pendidikan multikultural berprinsip pada demokrasi, kesetaraan, dan keadilan; (2) pendidikan multikultural berorientasi kepada kemanusiaan, kebersamaan, dan kedamaian; serta (3) pendidikan multikultural mengembangkan sikap untuk mengakui, menerima, dan menghargai keragaman budaya. ${ }^{11}$

Hanley mengatakan bahwa pendidikan multikultural berkait dengan perubahan sosial melalui pendidikan. Perubahan yang mengarah kepada pentingnya imajinasi, pengembangan gagasan, pemikiran dan komitmen membangun pandangan inklusif dan bukan eksklusif, menghargai perbedaan dan bukan sensitif serta memusuhi setiap perbedaan. ${ }^{12}$

Belum banyak yang menyadari bahwa kehidupan semakin majemuk. Namun, paradigma pendidikan belum diubah. Pendidikan masih menggunakan paradigma tunggal, budaya tunggal, kehendak, keinginan, dan harapan tunggal. Cara melayani dan mengelola pun dengan perspektif tunggal. Kebenaran pun dianggap tunggal. Satu-satunya kebenaran adalah menurut perspektif, pandangan, keyakinan, dan pikiran sendiri. ${ }^{13}$

Kemajemukan masyarakat memberikan dampak positif. Namun, disisi lain juga menimbulkan dampak negatif, karena faktor kemajemukan itulah justru terkadang menimbulkan konflik antar kelompok masyarakat. Bukti nyata tentang maraknya kerusuhan dan konflik yang berlatar belakang suku, adat, ras, dan utamanya agama menunjukkan bahwa pendidikan kita belum sepenuhnya sukses dalam menciptakan kesadaran akan pentingnya multikulturalisme. Fakta tersebut sebenarnya menunjukkan kegagalan pendidikan dalam menciptakan kesadaran pluralisme dan multikulturalisme.

9 James A. Banks, Multiethnic Education: Theory: Theory and Practice, cet. 2, (Boston: Allyn and Bacon 1988), hlm. 4

10 Soner Polat, "The Attitude of School Directos to Multicultural Education in Turkey", (Mediterrean Journal of Social Sciences, 2011), vol. 2, No. 2, May. hlm 385

11 Abdullah Aly, Pendidikan Islam Multikultural di Pesantren: Telaah Terhadap Kurikulum

Pondok Pesantren Modern Islam, (Yogyakarta: Pustaka Pelajar, 2011), Hlm 109

12 Zainuddin Maliki, Sosiologi Pendidikan, (Yogyakarta: Gadjah Mada University Press, 2008), Hlm 254

13 Ibid 
Dalam menghadapi pluralisme budaya tersebut, diperlukan paradigma baru yang lebih toleran, yaitu paradigma pendidikan multikultural. Akan menjadi penting karena mengarahkan para anak didik untuk bersikap dan berpandangan toleran dan inklusif terhadap realitas masyarakat yang beragam, baik dalam hal budaya, suku, ras etnis maupun agama. Paradigma ini dimaksudkan bahwa, hendaknya masyarakat ikut apresiatif terhadap budaya masyarakat lain. Perbedaan dan keberagaman merupakan kekayaan dan khazanah bangsa yang sudah sepatutnya dijaga bersama dengan saling menghargai. Dengan pandangan tersebut, diharapkan sikap membenarkan pandangan sendiri dengan menyalahkan pandangan dan pilhan orang lain dapat dihilangkan atau diminimalisir. ${ }^{14}$ Pendidikan multikultural juga merupakan bagian dari pembangunan mental peserta didik yang merupakan unsur-unsur pembangunan karakter dalam tranformasi pengetahuan. Hal ini, menunjukan bahwa pendidikan multikultural juga sejalan dengan pendidikan karakter.

Pendidikan multikultural dari kajian agama Islam bermuara dari perangkat ajaran dan nilai, yang meletakkan konsep dan doktrin yang merupakan rahmat li al-'alamin. Sebagai agama yang membawah misi sebagai rahmatan bagi seluruh dunia. Islam mengajaran umatnya dengan nilai-nilai normatif untuk menghargai dimensi pluralis-multikultural. Islam memandang dan menempatkan martabat dan harkat manusia baik sebagai makhluk individu maupun sebagai anggota sosial dengan baik tanpa pengecualian.

\section{Prinsip-Prinsip Pendidikan Multikultural}

Sebuah pendidikan multikultural diperlukan sebuah prinsip yang dijadikan sebuah landasan untuk bergerak, karena menginggat pentingnya akan nuansa pendidikan multikultural untuk menjawab persoalan-persoalan dewasa ini, oleh karena itu peneliti mengkaji prinsip-prinsip pendidikan multikultural dari berbagai sumber yang dibutuhkan seperti dibawah sebagai berikut ini.

Pertama, pendidikan multikultural didasarkan kepada pada pedagogik kesetaraan manusia (equity pedagogy). Kedua, pendidikan multikultural ditunjukan kepada terwujudnya manusia Indonesia yang cerdas dan mengembangkan pribadi-pribadi indonesia yang menguasai ilmu pengetahuan dengan sebaik-baiknya. Ketiga, prinsip globalisasi tidak perlu ditakuti apabila bangsa ini mengetahui arah serta nilai-nilai baik dan buruk yang dibawahnya. ${ }^{15}$

Bentuk pendidikan multikultural ini menekankan hubungan manusia

14 Choirul Mahfud, Pendidikan Multikultural, (Yogyakarta: Pustaka Pelajar, 2006), Hlm $185-186$

15 Tilaar, H.A.R. ManifestoPendidikan Nasional:Tinjanan dari Perspektif Post Modernisme dan Studi Kultural. (Jakarta:Kompas, 2005), Hlm 110 
dalam semua bentuknya dan menggabungkan beberapa karakteristik. Dua bentuk program lainnya, yaitu program yang menuntut perbaikan kurikulum dalam rangka menekankan kontribusi sosial yang positif dari kelompok etnis dan budaya, sambil menggunakan riset tentang model belajar untuk meningkatkan prestasi siswa dan mengurangi ketegangan dalam ruangan kelas. Selain membicarakan pendidikan multikultural didalam bentuk penyajiannya dalam kurikulum, pendidikan multikultural dapat pula disajikan dalam pengertian pengertian pendidikan yang lebih luas yaitu dalam seluruh budaya lembaga pendidikan baik dalam keluarga, lingkungan sekolah maupun masyarakat luas. Dengan demikian, pendidikan multikultural lebih tepat disebut sebagai lingkungan sekolah pendidikan multikultural yang merupakan pengembangan budaya pluralisme dalam kehidupan sekolah sebagai lembaga masyarakat. Pendidikan multikultural dapat digunakan baik pada tingkat deskriftif dan normatif, yang menggambarkan isu-isu dan masalah-masalah pendidikan yang berkaitan dengan masyarakat multikultural. Pendidikan multikultural juga mencakup tentang pertimbangan terhadap kebijakan dan strategi pendidikan dalam masyarakat multikultural. Dalam konteks deskriptif ini, kurikulum pendidikan multikultural mestilah mencakup subjek seperti toleransi, tema tentang perbedaan etno-kultural dan agama bahaya diskriminasi penyelesaian konflik dan mediasi dan subjek lain yang relavan.

Melalui pendidikan multikulturalisme ini diharapkan akan dicapai suatu kehidupan masyarakat yang damai, harmonis, dan menjunjung tinggi nilainilai kemanusiaan sebagaimana yang telah diamanatkan dalam undangundang dasar. Untuk memahami paradigma dan implementasi pendidikan multikultural, kita perlu mengenal hakekat atau nilai-nilai dasar yang tercakup di dalamnya yaitu berupa:

a. Al-Ukbuwah, Persaudaraan

b. Al-Hurriyah, Kebebasan

c. Al-Musawah, Kesetaraan

Kehidupan yang harmonis, toleran dan saling menghargai atas perbedaan masyarakat, pendidikan multikultural juga membutuhkan dialogical consensus yang memuat paling tidak tiga hal penting, yaitu negosiasi, kompromi, dan konsesus. ${ }^{16}$

\section{Karakteristik Pendidikan Multikultural}

Iklim dan budaya pendidikan multikultural tentu berbeda dengan pendidikan yang khusus. Pendidikan yang hanya mengambil satu sasaran agama, sosial, atau budaya tertentu. Sejalan dengan konsepnya pendidikan multikultural yang memiliki karakteristik berprinsip pada demokrasi, kesetaraan dan keadilan, berorientasi pada kemanusiaan, kebersamaan dan

16 M. Amin Abdullah, Pendidikan Agama Era Multikultural-Multireligius, (Jakarta: PSAP, 2005), Hlm 56 
kedamaian dan mengembangkan sikap mengakui, menerima dan menghargai. Dari karakteristik di atas dapat dijabarkan sebagai berikut ini.

\section{a. Berprinsip pada Demokrasi, Kesetaraan dan Keadilan}

Negara Amerika, Kanada, dan Jerman tidak membolehkan anakanak dari keluarga kulit hitam dan imigran untuk sekolah, sedangkan di negara Afrika, Banglades, Brazil, China, Mesir, India, Indonesia, Mexico, Nigeria, dan Pakistan terbatasnya untuk sekolah. Ini bertentangan dengan nilai demokrasi, kesetaran dan keadilan sebagai prinsip pendidikan multikultural. ${ }^{17}$

Setiap manusia mengakui kesetaraan antara manusia satu dengan yang lain. Pengakuan kesetaraan derajat, kesetaraan hak dan kesetaraan kewajiban sesama manusia. Kesetaraan penting dalam kondisi masyarakat yang beragam. Kesetaraan kedudukan, kewajiban dan hak sama dalam kehidupan di masyarakat sekitar, berbangsa dan bernegara. ${ }^{18}$

Demokrasi adalah sistem terbaik untuk menciptakan keadilan. Karena semua orang bebas berkarya tapi dibatasi oleh ideologi negara dan kepentingan umum; keterwakilan setiap kelompok untuk menjadi pemimpin; dan perselisihan politik diselesaikan secara damai dan demi kepentingan umum; peranserta rakyat menjadi lebih banyak orang memperoleh keadilan; dan inti demokrasi adalah pemantauan rakyat, dengan begitu penguasa tidak semena-mena. ${ }^{19}$

Keadilan terpenuhi sesudah terbentuk keadilan secara umum, yaitu semua orang mendapatkan haknya dan semua orang mendapatkan sama dari bagian aset yang dimiliki bersama Ada dua macam keadilan, yaitu keadilan khusus adalah keadilan berdasarkan keselamatan. Dan keadilan umum adalah keadilan yang ada dalam undang-undang yang wajib dilaksanakan untuk umum. ${ }^{20}$

\section{b. Berorientasi kepada kemanusiaan, kebersamaan dan kedamaian}

Nilai kemanusiaan seorang manusia itu secara alamiah dan sosial juga didasarkan pada kemampuannya menghargai kode etik dan sopan santun sebagai makhluk berbudaya yang tidak liar. Dalam kehidupan sehari-hari, manusia dihargai bukan karena bangunan tubuhnya yang indah, akan tetapi karena kualitas perbuatannya yang didasarkan pada kematangan pemikiran dan kesadaran yang membentuk sikap hidup yang bijak. Kapasitas akal manusia itulah yang menjadi ciri utama

17 Choirul Mahfud, Pendidikan Multikultural...hlm. 185-186.

18 Herimanto, Ilmu Sosial dan Budaya Dasar, (Jakarta: PT Bumi Aksara, 2010), Hlm 98-99

19 Sukron Kamil, Islam dan Demokrasi Telaah Konseptual dan Historis, Jakarta: Gaya Media Pratama, 2002), Hlm 31

20 Agnes Windati, Hukum Berkeadilan Jender, (Jakarta: Kompas, 2005), Hlm 7 
kemanusiaan dan aktualitasnya dalam kehidupan kongrit. ${ }^{21}$

\section{c. Mengembangkan sikap mengakui, menerima, dan menghargai keragaman}

Sikap menerima, mengakui dan menghargai keragaman penting dalam hubungan sosial di masyarakat yang beranekaragam. Dalam masyarakat beragam ada bagian masyarakat yang dominan dan minoritas. Dengan sikap menerima, mengakui dan menghargai keragaman memunculkan hubungan harmonis. ${ }^{22}$

Hubungan antar kelompok berlandaskan atas saling percaya dan menghargai menjadikan terjaganya kelompok masing-masing. Dalam hubungan antara kelompok semacam ini tidak akan hilangnya identitas kelompok. Hubungan ini tidak ada kendali kelompok mayoritas terhadap kelompok minoritas. Setiap individu mampu menerima, menghormati dan membentuk kerjasama dengan kelompok yang berlainan ini dinamakan kompetensi kultural. Kemampuan berbudaya berasal dari pengetahuan dan bias kultural yang menjadikan perbedaan kultural. Proses penambahan kompetensi kultural membutuhkan penambahan pengetahuan, kreatifitas, sifat dan perbuatan yang memahamkan orang dan berhubungan secara efektif dengan orang yang mempunyai perbedaan kultur. ${ }^{23}$

\section{Tujuan dan Pendekatan Pendidikan Multikultural}

Pada dasarnya tujuan pendidikan multikultural selaras dengan tujuan pendidikn secara umum, yaitu mencetak peserta didik tidak hanya mampu mengembangkan potensi dirinya dalam penguasaan ilmu pengetahuan, seni dan teknologi, melainkan sekaligus mampu mengembangkan dan menerapkan nilai-nilai universal dalam kehidupan. Kemudian, secara spesifik Gorski menjelaskan bahwa tujuan dari pendidikan multikultural adalah sebagai berikut:
a. Setiap peserta didik mempunyai kesempatan untuk mengembangkan prestasi mereka.
b. Peserta didik belajar bagaimana belajar dan berpikir secara kritis.
c. Mendorong peserta didik untuk mengambil peran aktif dalam pendidikan, dengan menghadirkan pengalaman-pengalaman mereka dalam konteks belajar.
d. Mengakomodasi semua gaya belajar.
e. Mengapresiasi kontribusi dari kelompok-kelompok yang berbeda.
f. Mengembangkan sikap positif terhadap kelompok-kelompok

21 Musthafa Rahman, Humanisasi Pendidikan Islam: Plus-minus Sistem Pendidikan pesantren, (Semarang: Walisongo Press, 2011), Hlm 56

22 Abdullah Aly, Pendidikan Islam....Hlm. 119

23 Zamroni, Pendidikan Demokrasi pada Masyarakat Multikultural, (Yogyakarta: Gavin Kalam Utama, 2011), Hlm 34-35 
yang mempunyai latar belakang yang berbeda.

g. Untuk menjadi warga yang baik di sekolah maupun di masyarakat.

h. Belajar bagaimana menilai pengetahun dari perspektif yang berbeda.

i. Untuk mengembangkan identitas etnis, nasional, dan global.

j. Mengembangkan keterampilan-keterampilan mengambil keputusan dan analisis secara kritis. ${ }^{24}$

\section{Nilai-nilai Pendidikan Multikultural}

Bannet menjelaskan nilai-nilai inti yang terkandung dalam pendidikan multikultural, antara lain:

a. Apresiasi terhadap adanya kenyataan pluralitas udaya dalam masyarakat

b. Pengakuan terhadap harkat manusia dan hak asasi manusia

c. Pengembangan tanggung jawab masyarakat dunia

d. Pengembangan tanggung jawab manusia terhadap planet bumi. ${ }^{25}$

Sedangkan UNESCO pada bulan Oktober 1994 di Jenewa telah merekomendasikan bahwa dalam pendidikan multikultural setidaknya harus memuat beberapa pesan. Rekomendasi tersebut di antaranya: Pertama, pendidikan hendaknya mengembangkan kemampuan untuk mengakui dan menerima nilai-nilai yang ada dalam kebhinekaan pribadi, jenis kelamin, masyarakat dan budaya serta mengembangkan kemampuan untuk berkomunikasi, berbagi dan bekerja sama dengan yang lain. Kedua, pendidikan hendaknya meneguhkan jati diri dan mendorong konvergensi gagasan dan penyelesaian-penyelesaian yang memperkokoh perdamaian, persaudaraan dan solidaritas antara pribadi dan masyarakat. ketiga, pendidikan hendaknya meningkatkan kemampuan menyelesaiakan konflik secara damai tanpa kekerasan. Karena itu, pendidikan hendaknya juga meningkatkan pengembangan kedamaian dalam pikiran peserta didik sehingga dengan demikian mereka mampu membangun secara lebih kokoh kualitas toleransi, kesabaran, kemauan untuk berbagi dan memelihara. ${ }^{26}$

\section{Implementasi Pendidikan Multikultural}

Bentuk pengembangan pendidikan multikultural di setiap negara berbeda-beda sesuai dengan permasalahan yang dihadapi masing-masing Negara. Banks (1993) mengemukakan empat pendekatan yang mengintegrasikan materi pendidikan multikultural ke dalam kurikulum maupun pembelajaran di sekolah yang bila dicermati relevan untuk diimplementasikan di Indonesia. Banks menjelaskan empat pendekatan untuk mengintegrasikan pendidikan multikultural ke dalam kurikulum atau

24 Syamsul Ma'arif, Pendidikan Pluralisme di Indonesia (Yogyakarta: Logung Pustaka, 2005), hlm, 95

25 Ngainun Naim dan Achmad Sauqi, Pendidikan Multikultural....Hlm. 213.

26 Salmiwati, Urgensi Pendidikan Agama Islam....., Hlm. 338 
materi pembelajaran disekolah. ${ }^{27}$

\section{HASIL PENELITIAN}

Hasil penelitian adalah fakta-fakta yang ditemukan dilapangan melalui wawacara, observasi dan juga dokumentasi, maka dengan itu peneliti akan mencoba memaparkan hasil penelitian berdasarkan fokus masalah sebagai berikut ini.

\section{Prinsip-prinsip implementasi Nilai Pendidikan Multikultural di} Prodi PGSD Universitas PGRI Palembang

Berbicara tentang prinsip-prinsip implementasi nilai pendidikan multikultural di prodi PGSD Universitas PGRI Palembang tidak terlepaas dari tiga prinsip-prinsip antara lain sebagai berikut ini.

\section{a. Prinsip Demokrasi}

Prinsip demokrasi adalah salah satu pondasi dalam penanaman nilai-nilai pendidikan multikultural di prodi PGSD Universitas PGRI Palembang, prinsip demokrasi adalah kesamaan hak, kebebasan berekpresi dan juga berkreasi tanpa adanya agama, golongan, suku tertentu yang lebih didominankan. Semua mahasiswa mempunyai hak yang sama untuk menjalankan ibadahnya, mempunyai hak yang sama untuk mendapatkan pelayanan yang prima dari kampus atau prodi tanpa ada perbedaan meskipun populasi yang beragama Islam masih menjadi dominan di prodi PGSD Universitas PGRI Palembang.

\section{b. Prinsip Kesetaraan}

Nilai kesetaraan mengacu pada keyakinan bahwa manusia diciptakan setara. Semua manusia diperlakukan kesetaraan memperoleh pendidikan, kesetaraan dimuka hukum dan kesetaraan. Setara dalam mengembangkan potensi yang dimaki setiap manusia. tidak adanya hak-hak superior pada setiap manusia. ${ }^{28}$

Prinsip kesetaraan menjadi rel atas perjalanan atau implementasi dari nilai-nilai pendidikan multukultural di Prodi PGSD Universitas PGRI Palembang. Kesetaraan hak dan derajat menjadi prioritas baik dalam segala hal, semua mahasiswa mempunyai kesetaraan dalam mendapatkan fasilitas kampus dan menpunyai peluang yang sama dalam hal menjalankan agama atau ritual keagamaan, tanpa ada intervesi atau pelarangan disebabkan berbeda dari agama yang dominan di kampus tersebut.

\section{c. Prinsip Keadilan}

Kemudian prinsip yang terakhir adalah prinsip keadilan, dimana keadilan menjadi pondasi yang terakhir dalam implementasi nilai-nilai

27 Yaya Suryana dan H.A Rusdiana, Pendidikan Multikultural. (Bandung: Pustaka Setia, 2015), Hlm 211

28 Rumadi, ed, Membangun Demokrasi Dari Bawah, ( Jakarta: PPSDM UIN Jakarta, 2006), Hlm 6 
pendidikan multikultural di Prodi PGSD Universitas PGRI Palembang. Adil adalah menempatkan sesuatu pada tempatya, yakni memberikan perlakuan atau pelayanan yang semestinya kepada seluruh mahasiswa tanpa ada yang menjadi anak kandung dan anak tiri, artinya semua sama baik berkenaan dangan reward dan punisment. Keadilan pelayanan akademik bagi seluruh mahasiswa, keadilan hak untuk mendapatkan fasilitas yang sama dan juga keadilan hukum dan aturan yang berlaku disana.

2. Penanaman nilai-nilai pendidikan multikultural di Prodi PGSD Universitas PGRI Palembang

Implementasi pendidikan multikultural di Universitas PGRI Palembang dapat dikatakan sangat baik, hal ini dapat dilihat dari:

a. Menciptakan suasana lingkungan kampus yang multikultur, sehingga mahasiswa terbiasa dengan adanya perbedaan di lingkungan sekitar mereka dan dapat hidup harmonis dengan perbedaan itu. Tujuannya agar mahasiswa memiliki jiwa toleransi, menghargai sesama, menghormati sesama, dan lain sebagainya. Selain itu kampus sangat menjunjung tinggi budaya ketimuran.

b. Penanaman nilai-nilai multikultural di wujudkan dalam kelas yaitu melalui kegiatan pembelajaran dimana banyak terdapat dalam pembelajaran sosiologi dan pendidikan agama. Dimana dua matakuliah ini sangat mempunyai peran penting dalam menguatkan nilai-nilai pendidikan multikultural. Selain melalui pendidikan di kelas penanaman nilai-nilai multikultural juga diwujudkan melalui kegiatan-kegiatan kampus diluar pembelajaran yaitu melalui kegiatan ibadah yang dilakukan oleh masing-masing mahasiswa setiap hari mulai dari agama Islam, Kristen, Katolik, Hindu, dan Budha. Sistem pembagian kelas belajar, dimana setiap kelas harus diisi oleh mahasiswa dari daerah berbeda bahkan dari agama yang berbeda.

c. Kurikulum yang digunakan oleh Universitas PGRI Palembang seperti di kampus lainnya yaitu menggunakan Kuikulum Kerangka Kualifikasi Nasional Indonesia (KKNI). Kurikulum Universitas PGRI Palembang terintegrasi dengan nasionalisme.

3. Implikasi penanaman nilai-nilai pendidikan multikultural terhadap sikap toleransi mahasiswa Universitas PGRI Palembang

Implementasi nilai-nilai pendidikan multikultural di prodi PGSD Universitas PGRI Palembang memberikan implikasi dan dampak yang positif terhadap sikap toleransi antar sesama mahasiswa baik dilingkungan kampus maupun diluar kampus, sikap menghargai, menghormati, membiarkan adalah sikap yang dihabituasikan mahasiswa tanpa ada 
intervensi, pelarangan, mencaci, menjelekkan antar umat beragama di Universitas PGRI terkhusus di prodi PGSD.

Dari hasil observasi dan juga wawancara yang mendalam dapat menggambarkan kematangan mahasiswa PGSD dalam bertoleransi, meskipun berbeda agama mereka tetap rukun dan saling menghargai satu sama lainnya. Meskipun banyaknya media yang mendeskriditkan agamaagama tertentu namun mereka menganggap bahwa itu adalah oknumoknum yang tidak bertanggung jawab yang mencoba mengadu domba antar ummat beragama. Meskipun di prodi PGSD yang mendominasi adalah yang beragama Islam, namun dominasi mereka tidak membuat populasi minoritas menjadi tidak nyaman dan terganggu dalam melaksanakan ritualritual keagamaan.

Meskipun secara keseluruhan dari sikap-sikap toleransi yang ditampilkan masih ada sikap yang menurut ajaran agam Islam adalah sikap toleransi yang harus diwaspadai atau berhati-hati, karena ditakutkan melanggar batas-batas torleransi yang sudah ditetapkan boleh dan tidak bolehnya dalam ajaran Islam. Itu terjadi adalah disebabkan beberapa kemungkinan antara lain adalah kurangnya pemaham tentang ajaran Islam dan bagaimana batasan-batasan bertoleransi dalam Islam.

\section{KESIMPULAN}

Implementasi nilai-nilai pendidikan multikultural di Universitas PGRI prodi PGSD didasari tiga prinsip, antara lain prinsip demokrasi, prinsip kesetaraan dan prinsip keadilan. Tiga prinsip ini yang manjadi pondasi implementasi nilainilai pendidikan multikultural dilingkungan Universitas PGRI. Kemudian berkenaan tentang implementasi nilai-nilai pendidikan multikultural dilasanakan melalui pendidikan formal yakni proses belajar di kampus dan juga pendidikan non formal yakni diluar proses belajar di kelas, antara lain lewat organisasi intra dan ekstra kampus, selain itu juga dilakukan dilingkungan asrama mahasiswa, pelayanan akdemik yang prima menjadi wilayah penanaman nilai-nilai pendidikan multikultural. Kemudian implementasi nilai-nilai pendidikan multikultural ini sangat berimplikasi terhadap sikap-sikap toleransi antar sesama mahasiswa, pegawai, dosen dilingkungan universitas.

\section{DAFTAR PUSTAKA}

A.Banks, James, 1998, Multiethnic Education: Theory: Theory and Practice, cet. 2, Boston: Allyn and Bacon

Abdullah, M. Amin, 2015, Pendidikan Agama Era Multikultural-Multireligius, Jakarta: PSAP.

Aly, Abdullah, 2011, Pendidikan Islam Multikultural di Pesantren: Telaah Terbadap Kurikulum Pondok Pesantren Modern Islam, Yogyakarta: Pustaka Pelajar. 
134 | AR-RIAYAH : Jurnal Pendidikan Dasar vol. 3, no. 2, 2019

Arikunto, Suharsimi, 1996, Prosedur Penelitian Suatu Pendekatan Praktek, Jakarta: Rineka Cipta.

E. Slavin, Robert, 2011, Psikologi Pendidikan; Teori dan Praktik, terj. Marianto Samosir, Jakarta: Indeks.

Hasyim, H.A. Dardi dan Hartono, Yudi, 2009, Pendidikan Multikultural di Sekolah, Surakarta: UPT penerbitan dan percetakan UNS.

Herimanto, 2010, Ilmu Sosial dan Budaya Dasar, Jakarta: PT Bumi Aksara,

Kamil, Sukron. 2002, Islam dan Demokerasi Telaab Konseptual dan Historis, Jakarta: Gaya Media Pratama.

Ma'arif, Syamsul. 2005, Pendidikan Pluralisme di Indonesia, Yogyakarta: Logung Pustaka.

Mahfud, Choirul, 2010, Pendidikan Multikultural, Jogjakarta: Pustaka Pelajar.

Maksum, Ali, 2011, Pluralisme dan Multikulturalisme; Paradigma Baru Pendidikan Agama Islam di Indonesia, Malang: Aditya Media Publishing.

Maliki, Zainuddin. 2008. Sosiologi Pendidikan. Yogyakarta: Gajah Mada University Pers.

Naim, Ngainun dan Sauqi, Achmad, 2011, Pendidikan Multikultural: Konsep dan Aplikasi, Jogjakarta: Ar-Ruzz Media

Polat, Soner. 2011, "The Attitude of School Directos to Multicultural Education in Turkey", Mediterrean Journal of Social Sciences, vol. 2, No. 2.

Rahman, Musthafa, 2011, Humanisasi Pendidikan Islam: Plus-minus Sistem Pendidikan pesantren, Semarang: Walisongo Press.

Rumadi. 2006. Membangun Demokrasi dari Bawah. Jakarta: PPSDM UIN Jakarta.

Salmiwati, 2013, Urgensi Pendidikan Agama Islam dalam Pengembangan Nilai-Nilai Multikultural, Jurnal Al-Ta lim Vol. 20, No. 1.

Sugiyono. 2009. Metode Penelitian Kualititatif dan R\&D. Bandung: Alfabeta.

Suryana, Yaya dan Rusdiana, H.A, 2015, Pendidikan Multikultural, Bandung: Pustaka Setia.

Tilaar, H.A.R. 2005. Manifesto Pendidikan Nasional: Tinjauan dan Perspektif Post Modernisme dan Studi Kultural. Jakarta: Kompas.

Windati, Agnes. 2005, Hukum Berkeadilan Jender, Jakarta: Kompas.

Zamroni. 2011, Pendidikan Demokrasi pada Masyarakat Multikultural, Yogyakarta: Gavin Kalam Utama. 